\title{
Manajemen P0AC Pada Masa Pandemi Covid-19 Terhadap Pembelajaran Luring Di SDII Luqman AI Hakim Batam
}

\author{
Nurhayati \\ Lias Hasibuan \\ Kasful Anwar \\ Universitas Islam Negeri Sultan Thaha Saifuddin, Indonesia \\ nurhayatirazeq@gmail.com,Lhas10@yahoo.co.id, \\ kasfulanwarus@gmail.com
}

\begin{abstract}
This study aims to describe the implementation of learning during the Covid-19 pandemic seen from the management theory of POAC (Planning, Organizing, Actuating, Controlling). The research approach used is a qualitative approach with a case study method. The research was carried out by SDII Luqman Al Hakim Batam. The research subject is the principal, while the informants are all structural members in the school, the teacher council and several students who were selected using purposive sampling technique. Data were collected through interviews and documentation. Data analysis used the Miles and Huberman model. The results of the study show that the principal applies management functions according to the POAC theory in its implementation during the covid-19 pandemic, namely: 1) planning, namely collecting data on students who will be divided into 2 shifts during offline learning; 2) organizing, which divides students into two study groups, namely
\end{abstract}


shift 1 and shift 2; 3) actuating, namely the introduction of facilities and infrastructure to the covid-19 protocol available in schools during the implementation of offline learning; and 4) controlling, namely the evaluation of offline learning at the school level which is carried out at the end of the 2020/2021 school year

Keywords: Planning, Organizing, Actuating, Controlling, Offline

Abstrak: Penelitian ini bertujuan untuk mendeskripsikan pelaksanaan pembelajaran selama pandemi Covid-19 dilihat dari teori manajemen POAC (Planning, Organizing, Actuating, Controlling). Pendekatan penelitian yang digunakan adalah pendekatan kualitatif dengan metode studi kasus. Penelitian dilaksanakan SDII Luqman Al Hakim Batam. Subjek penelitian adalah kepala sekolah, sedangkan informan adalah semua struktural di sekolah, dewan guru dan beberapa siswa yang dipilih menggunakan teknik purposive sampling. Data dikumpulkan melalui wawancara dan dokumentasi. Analisis data menggunakan model Miles and Huberman. Hasil penelitian menunjukkan kepala sekolah menerapkan fungsi manajemen sesuai dengan teori POAC dalam pelaksanaannya selama pandemi covid-19 yaitu: 1) planning, yaitu melakukan pendataan peserta didik yang akan dibagi 2 sift selama pembelajaran luring; 2) organizing, yaitu membagi peserta didik menjadi dua kelompok belajar, yaitu sift 1 dan sift $2 ; 3$ ) actuating, yaitu pengenalan sarana dan prasarana terhadap protokol covid-19 yang tersedia disekolah selama pelaksanaan pembelajaran luring; dan 4) controlling, yaitu pelaksanaan evaluasi pembelajaran luring di tingkat sekolah yang dilakukan pada akhir tahun pelajaran 2020/2021

Kata Kunci: Planning, Organizing, Actuating, Controlling, Luring

\section{Pendahuluan}

Pendidikan yang berkualitas menentukan kualitas suatu bangsa menuju kehidupan yang maju dan bertamartabat. UU No 20 Tahun 2003 tentang sistem pendidikan Nasional diawali dengan melaksanakan pembaruan kurikulum, peningkatan kebutuhan tenaga pendidik, 
penyediaan sarana dan prasarana, perbaikan kesejahteraan tenaga pendidik, perbaikan organisasi, manajemen dan pengawasan. ${ }^{1} \mathrm{Hal}$ ini sangat penting untuk dilaksanakan, terkait dengan mutu sumber daya manusia. Manajemen merupakan hal yang paling sering dibicarakan dalam bidang akademik maupun praktik. Oleh karena itu, pemerintah memberikan amanah kepada semua satuan pendidikan baik di tingkat pendidikan dasar, menengah maupun tinggi untuk menyelenggarakan pendidikan yang bermutu dalam kondisi apapun, termasuk di masa krisis pandemi Covid-19 yang melanda dunia saat ini.

Dalam rangka pelaksanaan BDR di masa pandemi Covid-19, Menteri Pendidikan dan Kebudayaan Republik Indonesia mengeluarkan Surat Edaran Mendikbud Nomor 4 Tahun 2020 tanggal 24 Maret 2020 tentang Pelaksanaan Kebijakan Pendidikan dalam Masa Darurat Penyebaran Coronavirus Disease (Covid-19). Surat Edaran tersebut kemudian diperjelas lagi melalui Surat Edaran Sekretaris Jenderal Kemdikbud Republik Indonesia Nomor 15 Tahun 2020 tentang Pedoman Pelaksanaan Belajar Dari Rumah (BDR) selama Darurat Bencana. Surat Edaran Mendikbud RI Nomor 4 Tahun 2020 berisi tujuh prinsip yang harus dilaksanakan oleh satuan pendidikan selama pelaksanaan BDR. Sedangkan Surat Edaran Sekretaris Jenderal Kemendikbud Nomor 15 Tahun 2020 menjelaskan tentang metode pelaksanaan BDR yang dapat diterapkan yaitu dengan pembelajaran jarak jauh dalam jaringan (daring) dan atau pembelajaran jarak jauh luar jaringan (luring).

Pandemi Covid-19 merupakan krisis kesehatan yang terjadi di dunia saat ini. Virus ini sangat cepat menyebar dan meluas sampai di seluruh dunia yang mengakibatkan kerugian besar di berbagai sektor. Menurut Khasanah dkk, salah satu sektor yang mengalami dampak dari pendemi ini adalah pendidikan. Banyak negara memutuskan untuk menutup sekolah, perguruan tinggi dan universitas sebagai upaya untuk memutus rantai penyebaran Covid-19. ${ }^{2}$

1 Depdiknas, Undang-Undang RI No 20 tahun 2003 Tentang Sistem Pendidikan Nasional.

2 Agus Purwanto, Masduki Asbari, dkk. Studi Eksploratif Dampak Pandemi COVID 19 Terhadap Proses Pembelajaran Online di Sekolah Dasar, Edu Psy Couns Journal 
Berdasarkan surat edaran Sekretaris Jenderal Kemendikbud Nomor 15 Tahun 2020 diatas, maka setiap satuan pendidikan diharapkan dapat menerapkan salah satu atau kedua moda BDR tersebut, yaitu moda daring dan moda luring, tidak terkecuali di SDII Luqman Al Hakim Batam. Pemilihan moda yang akan digunakan tergantung dari kondisi wilayah dan sumber daya yang dimiliki oleh satuan pendidikan dan kondisi siswa. SDII Luqman Al Hakim Batam merupakan salah satu sekolah yang menggunakan moda luring di kota Batam. Kondisi ini dilakukan karena anak SD belum bisa secara mandiri menggunakan gadget untuk mengerjakan melakukan pembelajaran moda daring. Mereka masih harus dibantu orang tua dan dibimbing. Sehingga semua proses pembelajaran tergantung bagaimana dan kapan orang tua ada waktu mendampingi anak-anak belajar dan mengerjakan tugasnya. Tentu hal ini sangat jauh berbeda untuk anak SMP dan SMA yang sudah bisa menggunakan gadget dan media pembelajaran lain yang lebih inovatif dan kreatif sesuai perkembangan zaman seperti Zoom Meeting, Microsoft Ofiice 365 dan metode pembelajaran lainnya.

Berbagai kondisi tersebut, tentu tidak menggugurkan kewajiban sekolah untuk memberikan layanan pendidikan bagi peserta didik. Oleh karena itu, dalam rangka pemenuhan hak belajar peserta didik selama masa pandemi Covid-19, maka kepala sekolah SDII Luqman Al Hakim Batam selaku pimpinan sekaligus manajer di sekolah menerapkan fungsi manajerial dalam pelaksanaan kebijakan moda luring sesuai dengan teori POAC (Planning, Organizing, Actuating, Controlling). ${ }^{3}$ Dengan penerapan fungsi manajemen tersebut, diharapkan pelaksanaan moda luring oleh guru dengan melakukan pembelajaran dibagi 2 sift yaitu sift 1 dan sift 2 yang akan mencapai hasil yang maksimal ditengah berbagai keterbatasan dan kendala yang dihadapi. Hal ini sesuai dengan pernyataan Yuniati \& Prayoga (2019) bahwa manajemen pembelajaran memiliki peran penting terhadap kinerja mengajar guru. Jika manajemen pembelajaran tidak direncanakan dan dilaksanakan dengan baik, maka mustahil sebuah program akan berhasil dengan baik.

Volume 2, Nomor 1. 2020.

3 G. R. Terry, Asas-Asas Manajemen (Bandung: Alumni, 2006), h. 11. 
Suatu organisasi untuk mencapai sasaran yang sudah ditetapkan sebelumnya, akan sukses apabila organisasi tersebut dapat menjalankan fungsi manajemen dengan baik diantaranya dapat berupaya mengorganisir, memberikan pengarahan kerja, mengkordinasi dalam usaha untuk menjalankan rencana yang telah ditetapkan, serta mampu menjalankan pengawasan implementasi kerja. Apabila tidak ada planning yang baik, dapat dapat dipastikan suatu organisasi akan mengalami kegagalan atau kemunduran. Suatu perencanaan pada dasarnya menetapkan apa yang dilakukan, bagaimana, dan siapa yang melakukan, sebelum aktivitas itu sendiri dikerjakan. Maka untuk mencapai tujuan ini semua maka maka pemimpin lembaga pendidikan menggunakan sumber daya dan melaksanakan empat fungsi pengelolaan pendidikan yaitu POAC (Planning, Organizing, Actuating, Controlling).

Berdasarkan uraian di atas, maka permasalahan yang terjadi adalah bagaimana pelaksanaan moda luring di masa pandemi Covid-19 di SDII Luqman Al Hakim ditinjau dari fungsi manajemen sesuai dengan teori POAC. Sedangkan tujuan penelitian ini adalah untuk mendeskripsikan pelaksanaan moda luring di masa pandemi Covid-19 di SDII Luqman Al Hakim Batam ditinjau dari fungsi manajemen sesuai dengan teori POAC.

\section{Metode Penelitian}

Pendekatan dalam penelitian ini adalah pendekatan kualitatif dengan metode studi kasus. Sedangkan subjek dalam penelitian ini adalah kepala sekolah, dan sebagai informan adalah semua struktural di sekolah, semua dewan guru dan peserta didik. Metode pemilihan sumber data ini adalah purposive sampling. Lokasi penelitian di SDII Luqman Al Hakim Batam. Penelitian dilaksanakan pada semester I (Ganjil) sampai semester II (Genap) Tahun Pelajaran 2020/2021, yaitu sejak BDR mulai dilaksanakan tepatnya sejak bulan Juli 2020 sampai bulan Juni 2021. Data dikumpulkan melalui wawancara kepada kepala sekolah, kour kurikulum dinas, kour kesiswaan, dewan guru dan peserta didik selama pelaksanaan moda luring dimasa pandemi Covid-19. Selain itu, data juga dikumpulkan melalui dokumen pelaksanaan moda luring dimasa pandemic Covid-19. Dokumen yang dimaksud adalah absensi pelaksanaan moda luring, jadwal 
pelajaran, pembagian kelompok (sift 1 dan sift 2), jadwal sift 1 dan sift 2, dan dokumentasi moda luring.

Table 1. Jumlah Peserta Didik pada Pembelajaran Moda Luring

\begin{tabular}{|c|c|c|}
\hline Kelas & Sift 1 & Sift 2 \\
\hline $1 \mathrm{~A}$ & 13 & 14 \\
\hline 1B & 14 & 14 \\
\hline $1 \mathrm{C}$ & 13 & 13 \\
\hline 1D & 14 & 14 \\
\hline $2 \mathrm{~A}$ & 14 & 12 \\
\hline $2 B$ & 11 & 14 \\
\hline $2 \mathrm{C}$ & 14 & 11 \\
\hline $2 \mathrm{D}$ & 13 & 13 \\
\hline $2 \mathrm{E}$ & 14 & 12 \\
\hline $3 \mathrm{~A}$ & 12 & 14 \\
\hline $3 B$ & 15 & 11 \\
\hline $3 \mathrm{C}$ & 13 & 13 \\
\hline $3 \mathrm{D}$ & 14 & 12 \\
\hline $3 \mathrm{E}$ & 14 & 13 \\
\hline $4 \mathrm{~A}$ & 10 & 17 \\
\hline $4 B$ & 12 & 15 \\
\hline $4 \mathrm{C}$ & 15 & 11 \\
\hline $4 \mathrm{D}$ & 13 & 13 \\
\hline $4 \mathrm{E}$ & 12 & 13 \\
\hline $5 \mathrm{~A}$ & 16 & 14 \\
\hline 5B & 18 & 12 \\
\hline $5 \mathrm{C}$ & 13 & 17 \\
\hline $5 \mathrm{D}$ & 12 & 14 \\
\hline $5 \mathrm{E}$ & 16 & 12 \\
\hline $5 F$ & 10 & 13 \\
\hline $6 \mathrm{~A}$ & 16 & 14 \\
\hline $6 B$ & 15 & 15 \\
\hline $6 \mathrm{C}$ & 18 & 11 \\
\hline 6D & 13 & 17 \\
\hline $6 \mathrm{E}$ & 13 & 17 \\
\hline
\end{tabular}


Table 2. Jadwal Pembelajaran Moda Luring

\begin{tabular}{|c|c|c|c|}
\hline Waktu & Senin \& Selasa & Rabu \& Kamis & Jum’at \& Sabtu \\
\hline $07.15-07.30$ & ADMT & ADMT & MTK \\
\hline $07.30-08.30$ & AL-QUR'AN & AL-QUR'AN & TEMATIK \\
\hline $08.45-09.45$ & B.INGGRIS & TENATIK & TEMATIK \\
\hline $10.00-11.00$ & TEMATIK & PAI & B.ARAB \\
\hline
\end{tabular}

Data yang dikumpulkan selanjutnya dianalisis dengan menggunakan model Miles and Huberman. Langkah dalam analisis data menurut Miles and Huberman adalah data reduction, data display, dan conclusion drawing/verification. ${ }^{4}$

\section{Pembahasan 1}

Sebagai upaya untuk menekan penyebaran virus Covid-19 pada masa pandemi Covid-19, maka penyelenggaraan pembelajaran dibagi 2 kelompok atau dibagi 2 sift di SDII Luqman Al Hakim Batam dalam rangka penerapan jaga jarak sosial (social distancing) didalam kelas selama moda luring dimasa pandemic Covid-19. Maka, untuk model pembelajaran di kelas dibagi 2 kelompok dalam satu kelasnya. Sift 1 masuk selama 3 hari begitupula dengan sift 2. Jadwal sift 1 masuk pada hari Senin, Rabu dan Jumat. Sedangkan sift 2 masuk pada hari Selasa, Kamis dan Sabtu. Kepala Sekolah selaku manajer di lembaga pendidikan menerapkan fungsi manajemen sesuai dengan teori POAC (Planning, Organizing, Actuating, Controlling). Berikut ini digambarkan proses POAC yang dilaksanakan di SDII Luqman Al Hakim Batam dalam pelaksanaan pembelajaran moda luring pada masa Covid-19.

\section{Planning (Perencanaan)}

Menurut Terry dalam buku Riyadi, planning adalah upaya untuk memiih dan menghubungkan fakta-fakta dan membuat asumsi-asumsi mengenal masa yang akan dating dengan jalan menggambarkan dan merumuskan kegiatan-kegiatan yang diperhatikan untuk mencapai

\footnotetext{
${ }^{4}$ Sugiyono, Metode Penelitian Kualitatif (Bandung: Alfabeta, 2018), h. 26.
} 
hasil yang diinginkan. ${ }^{5}$ Dengan menyusun planning atau perencanaan yang jelas, akan memudahkan semua elemen dalam organisasi dalam menjalankan tugasnya masing-masing sehingga memberikan kontribusi untuk tercapainya tujuan organisasi.

Perencanaan pembelajaran moda luring di SDII Luqman Al Hakim Bata mini dilaksanakan dengan langkah pertama adalah mengumpulkan data peserta didik yang memiliki gawai/gadget. Pendataan ini dimulai pada minggu kedua bulan Juli 2020 pada masa pandemic Covid-19 ini merabah ke negeri kita tercinta ini sehingga mengakibatkan beberapa sekolah melaksanakan pembelajaran moda daring, sedangkan untuk SDII Luqman Al Hakim Batam ini menggunakan moda luring selama masa pandemic Covid-19 di awal tahun pelajaran baru 2020/2021. Tahap selanjutnya adalah merancang model pembelajaran yang akan digunakan di SDII Luman Al Hakim Batam ini yaitu moda luring. Langkah kedua adalah kour kurikulum membagi 2 sift untuk melaksanakan pembelajaran moda luring ini, meliputi pembagian 2 kelompok dalam satu kelas dengan istilah sift 1 dan sift 2, penyusunan Rencana Pelaksanaan Pembelajaran (RPP), penyusunan modul belajar siswa, pengembangan materi/bahan pembelajaran dan penyusunan kisi-kisi soal untuk kuis, jadwal UH, jadwal PTS, dan jadwal PAS secara luring.

\section{Organizing (Pengorganisasian)}

Pengorganisasian yaitu sebagai cara untuk mengumpulkan orangorang dan menempatkan mereka sesuai kemampuan dan keahliannya. ${ }^{6}$ Dengan kata lain, pengorganisasian merupakan kegiatan penataan sumberdaya organisasi untuk melaksanakan tugas dan fungsi. Kegiatan yang dilakukan di SDII Luqman Al Hakim Batam pada tahap pengorganisasian adalah dengan membagi peserta didik menjadi dua kelompok, yaitu kelompok Walas dan GBS. Guru yang memang layak menjadi walas maka akan diamanahkan sebagai walas atau guru tersebut lulusan PGSD, sedangkan guru yang memang belum layak menjadi walas atau

${ }^{5}$ Riyadi dan Deddy Supriyadi Bratakusumah, Perencanaan Pembangunan Daerah (Jakarta: PT Gramedia Pustaka Utama. 2005), h. 3.

6 G. R. Terry, Asas-Asas Manajemen ..., h. 24. 
mempunyai kompetensi dibidang keilmuan lain maka akan diamanahkan sebagai GBS (Guru Bidang Studi). GBS yang ada di SDII Luqman Al Hakim Batam ini adalah GBS PAI, Bahasa Inggris, Bahasa Arab, TIK dan PJOK. Kelompok Walas akan membuat group kelas atau walimurid, sedangkan kelompok GBS akan membuat group KKG GBS. Group kelas yang dibuat oleh para Walas berfungsi untuk menyampaikan berbagai informasi kelas selama pembejalaran moda luring dimasa pandemic Covid-19 ini. Sedangkan untuk group KKG GBS dibentuk dan dibuat untuk menyamakan pembelajaran bidang studi disemua kelas, mulai dari materi yang disampaikan serta media pembelajaran yang digunakan. Selama masa pandemic Covid-19 ini waktu pembelajaran moda luring ini sangat terbatas dan singkat sehingga membuat para Kour dan dewan guru harus inovatif, kreatif dan bisa membagi waktu pembelajaran ini secara efektif dan efisien dengan segala keterbatasan waktu yang tersedia sehingga semua materi pembelajaran selama masa pandemi Covid-19 ini bisa terlaksana dengan baik.

\section{Actuating (Penggerakan)}

Actuating adalah suatu tindakan untuk mengusahakan agar semua anggota kelompokberusaha mencapai sasaran yang sesuai dengan perencanaan managerial dan usaha-usaha organisasi. ${ }^{7}$ Dalam penggerakan (actuating) dilakukan sinkronisasi semua kegiatan dan penciptaan kerjasama dari seluruh lini, sehingga tujuan organisasi dapat dicapai dengan lancar dan efisien. Pada tahap penggerakan dalam moda luring ini adalah dengan membagi murid di kelas menjadi 2 kelompok sehingga protocol Covid-19 lebih terjaga dan kelas lebih kondusif dikarenakan hanya 10 sampai 18 saja jumlah anak di kelas.

Sedangkan pada tahap penggerakan bagi kelas luring dimasa pandemi Covid-19 ini adalah diisi dengan kegiatan pembelajaran di kelas sesuai jadwal pelajaran dan pembagian kelas yang dibagi 2 sift. Selain itu, semua peserta didik yang berada di kelas luring dibekali dengan buku paket cetak dan modul untuk digunakan selama BDR. Untuk kegiatan penilaian/ evaluasi pembelajaran pada BDR, maka dipilih penilaian yang sesuai

\footnotetext{
7 G. R. Terry, Asas-Asas Manajemen ..., h. 42.
} 
dan bisa dilaksanakan pada masa pandemi Covid-19. Bagi peserta didik yang melaksanakan pembelajaran secara luring, penilaian pembelajaran dilakukan dengan penilaian portofolio, kuis, soal latihan dll. Penilaian pembelajaran meliputi penilaian keaktifan peserta didik dalam diskusi, penilaian kuis di akhir materi, penilaian tugas/proyek, penilaian tengah semester (PAS), dan penilaian akhir semester (UAS).

\section{Controlling (Penilaian/Evaluasi)}

Pengawasan adalah suatu proses untuk menetapkan pekerjaan apa yang telah dilaksanakan, menilainya, dan juga mengoreksinya. ${ }^{8}$ Pengawasan dilakukan untuk mengukur hasil pekerjaan, guna menghindari penyimpangan-penyimpangan, dan jika diperlukan segera melakukan tindakan yang tegas terhadap berbagai penyimpangan yang terjadi. Penilaian yang dilakukan di SDII Luqman Al Hakim Batam selama masa pandemi Covid-19 ini dilakukan pada akhir tahun pelajaran 2020/2021 yaitu setelah kenaikan kelas 1 sampai kelas 5 dan setelah pengumuman kelulusan kelas 6. Berbagai kendala yang dihadapi guru dalam pelaksanaan BDR dengan moda luring selama masa pandemi Covid-19 ini didiskusikan dalam forum pra raker dan kemudian dicari solusi untuk diterapkan pada Tahun Pelajaran 2021/2022.

\section{Pembahasan 2}

Pembelajaran moda luring pada masa pandemi Covid-19 tidak dapat berjalan mulus dan efektif, karena terkadang sumber daya di sekolah belum siap. Kendala yang terjadi dalam pelaksanaan pembelajaran moda luring sangat kompleks. Kondisi guru-guru yang kurang kreatif dalam penyampaian materi di kelas juga salah satu penghambat pembelajaran moda luring selama masa pandemi Covid-19 ini, Waktu pembelajaran moda luring yang sangat terbatas ini dikarenakan siswa masuk 3 kali dalam sepekan dan itupun waktu atau durasi tatap muka yang sangat terbatas, sehingga menyebabkan banyak materi atau pembelajaran yang

8 Manullang, Dasar-dasar Manajemen Pendidikan (Yogyakarta: UGM Press, 2010), h. 173. 
belum tuntas sehingga guru memberikan tugas tambahan dirumah atau BDR. Sehingga Kour melakukan pelatihan dan pembinaan kepada dewan guru terutama walas dan GBS agar lebih kreatif dalam pembelajaran di kelas dan dalam pembuatan soal. Semua berjalan dengan baik dan terkontrol dikarenakan Kour dibagi 2 yaitu Kour Level Bawah untuk menangani level 1,2 dan 3, dan Level Atas untuk menangani level 4,5 dan 6 dengan adanya kontrol Kepala Sekolah dan kerjasama Tim Stuktural dari Kour Kurikulum, Kour Kesiswaan, Kour Sarpras dan semua tenaga kependidikan sehingga pembelajaran moda luring selama Pandemi Covid-19 dapat berjalan dengan baik.

Padahal peran guru dalam pembelajaran sangat berpengaruh terhadap efektifitas dan keberhasilan pembelajaran, terlebih pada masa tidak normal seperti masa pandemi Covid-19 sekarang ini dimana kreativitas guru dalam mengajar sangat diperlukan. Sesuai dengan pernyataan Dewi, bahwa kegiatan belajar dapat berjalan baik dan efektif sesuai dengan kreativitas guru dalam memberikan materi dan soal latihan kepada peserta didik, dari soal-soal latihan yang dikerjakan oleh peserta didik dapat digunakan untuk nilai harian peserta didik. Maka, peran kepala sekolah sebagai manajer pada satuan pendidikan menjadi sangat penting dalam mengelola dan memberdayakan sumber daya yang ada pada satuan pendidikan. Berdasarkan hasil penelitian yang telah diuraikan di atas, maka peneliti menganalisa bahwa pelaksanaan fungsi manajemen POAC telah diterapkan oleh kepala sekolah di SDII Luqman Al Hakim Batam, sehingga segala tantangan dan halangan terkait dengan pelaksanaan BDR moda luring dapat diatasi. Keberhasilan ini dapat dilihat dari partisipasi aktif dalam kegiatan BDR moda luring baik dari guru maupun dari peserta didik. Hasil penelitian ini sejalan dengan hasil beberapa peneliti terdahulu yang meneliti tentang penerapan manajemen POAC oleh kepala sekolah dalam berbagai program di sekolah, antara lain: 1) Dullah (2020) yang meneliti tentang manajemen POAC dalam program kesiswaan di SD; 2) Yudhistira (2019) yang meneliti tentang manajemen POAC dalam mencegah bahaya narkoba di SMA;3) Atabik (2019) yang meneliti tentang manajemen $\mathrm{POAC}$ dalam pendidikan karakter di pondok pesantren dan 4) Khairul Akbar (2021) yang meneliti Manajemen PAOC pada masa Pandemi Covid-19. 


\section{Penutup}

Kesimpulan yang diperoleh dari hasil penelitian ini adalah pelaksanaan manajemen moda luring oleh kepala sekolah di SDII Luqman Al Hakim Batam menerapkan teori POAC, dengan rincian kegiatan sebagai berikut: 1) planning, yaitu melakukan pendataan peserta didik dan membaginya menjadi 2 kelompok atau 2 sift dalam satu kelas selama pembelajaran moda luring, begitupula persiapan administrasi kelas seperti RPP dan penilaian dalam pembelajaran; 2) organizing, yaitu membagi peserta didik menjadi dua kelompok belajar, yaitu kelompok walas dan kelompok GBS; 3 ) actuating, yaitu pengenalan sarana dan prasarana yang digunakan dalam pembelajaran secara luring yang dilanjutkan dengan pelaksanaan BDR; dan 4) controlling, yaitu pelaksanaan evaluasi program BDR moda luring di tingkat sekolah dasar yang dilakukan pada akhir Tahun Pelajaran 2020/2021 untuk perbaikan pelaksanaan BDR di Tahun Pelajaran $2021 / 2022$. 


\section{DAFTAR PUSTAKA}

Akbar, Khairul. Manajemen POAC pada masa Pandemi Covid-19 (Studi Kasus BDR di SMP Negeri 2 Praya Barat Daya), Studi Manageria: Jurnal Kependidikan. 7, (1), 2021.

Atabik, Sauri, S., \& Rostini, D. Manajemen Pendidikan Karakter di Sekolah Dalam Lingkungan Pondok Pesantren Untuk Membina Akhlakul Karimah. Nusantara Education Revie. 3, (2), 2019.

Depdiknas. Undang-Undang RI No 20 tahun 2003 Tentang Sistem Pendidikan Nasional.

Dullah, Y. \& Munir. Manajemen Kesiswaan di SDIT (Sekolah Dasar Islam Terpadu) Harapan Mulia Palembang. Studi Manageria: Jurnal Manajemen Pendidikan Islam. 2, (1), 2020.

Manullang. Dasar-dasar Manajemen Pendidikan, Yogyakarta: UGM Press, 2010.

Purwanto, Agus., Masduki Asbari, dkk. Studi Eksploratif Dampak Pandemi COVID 19 Terhadap Proses Pembelajaran Online di Sekolah Dasar, Edu Psy Couns Journal Volume 2, Nomor 1. 2020.

Riyadi dan Deddy Supriyadi Bratakusumah. Perencanaan Pembangunan Daerah, Jakarta: PT Gramedia Pustaka Utama, 2005.

Sugiyono. Metode Penelitian Kualitatif, Bandung: Alfabeta, 2018.

Terry, G. R. Asas-Asas Manajemen, Bandung: Alumni, 2006.

Yudhistira, A. M. Manajemen Kepala Sekolah dalam Mencegah Bahaya Narkoba di SMA Negeri Karang Jaya Kab. Musi Rawas Utara. AnNizom. 4, (3), 2019. 
